\title{
Przedsiębiorczość polskich prawników
}

\author{
Marek Gnusowski*
}

Polski rynek ustug prawnych ulega w ostatnich latach znaczacym przeksztatceniom. Można zauważyć zmianę charakteru i sposobu wykonywania zawodów adwokata i radcy prawnego. Prawnicy sa coraz powszechniej uważani za przedsiębiorców i traktowani jak komercyjni ustugodawcy, a nie jak profesjonaliści, realizujący określona misję zawodowa. W tym kontekście oczekuje się od nich nie tylko wiedzy, doświadczenia i umiejętności zawodowych, ale również zdolności prowadzenia przedsiębiorstwa $i$ konkurowania na rynku. $W$ artykule przedsiębiorczość ujęta zostanie przez pryzmat teorii kompetencji, a co za tym idzie zostanie wskazany zbiór cech i umiejętności stanowiących formę przedsiębiorczych dziatań prawników.

Słowa kluczowe: przedsiębiorczość, usługi prawne, kompetencje.

Nadesłany: 12.07.2015 | Zaakceptowany do druku: 28.09.2015

\section{Entrepreneurship of Polish Lawyers}

Polish legal services market is developing fast. The role of Polish lawyers has changed and they are often seen as entrepreneurs who need to compete for customers, not only as professionals. There is no substantial amount of literature covering this subject in the realities of legal services and the existing publications are fragmented and do not provide a comprehensive overview. The aim of the study is to formulate the list of factors of entrepreneurship of Polish lawyers, which contribute to their prosperity. A theory of entrepreneurial competences will be used.

Keywords: entrepreneurship, legal services, competences.

Submitted: 12.07.15 | Accepted: 28.09.2015

JEL: L26, L84

\footnotetext{
* Dr Marek Gnusowski, Uniwersytet Ekonomiczny w Poznaniu, Wydział Zarządzania, Katedra Badań Rynku i Usług.

Adres do korespondencji: Uniwersytet Ekonomiczny w Poznaniu, Wydział Zarządzania, Katedra Badań Rynku i Usług, Al. Niepodległości 10, 61-875 Poznań, e-mail: marek.gnusowski@ue.poznan.pl.
} 


\section{Wprowadzenie}

Proces transformacji oraz częściowe otwarcie dostępu do zawodów prawniczych znacząco zmieniły ustrojową i zawodową pozycję prawników. Obserwując kierunki i intensywność zmian, należy stwierdzić, że rynek usług prawnych znajduje się w przełomowym momencie. Dostrzegalne są zwłaszcza zjawiska przekształcania rynku sprzedawcy w rynek nabywcy oraz fakt, że prawnicy są coraz częściej zmuszeni do konkurowania o klientów. Widoczna jest też zmiana charakteru i sposobu wykonywania zawodu adwokata i radcy prawnego. Prawnicy sa coraz powszechniej uważani za przedsiębiorców i traktowani jak komercyjni usługodawcy, a nie jak profesjonaliści, będący przedstawicielami wolnego zawodu, realizujący określoną misję zawodową. Jako od przedsiębiorców, oczekuje się od nich nie tylko wiedzy, doświadczenia i umiejętności zawodowych, ale również umiejętności prowadzenia przedsiębiorstwa, konkurowania na rynku i porozumiewania się $\mathrm{z}$ otoczeniem. Mając na uwadze powyższe, celem autora artykułu, oprócz wykazania, że w obecnej sytuacji gospodarczej i prawnej prawników należy uznawać za przedsiębiorców, jest przede wszystkim wskazanie cech decydujących o przedsiębiorczości tej grupy zawodowej. Posiadanie tych cech pozwala z powodzeniem zdobywać i utrzymywać klientów na konkurencyjnym rynku usług prawnych. Wobec faktu, że autor dostrzega wieloznaczność pojęcia „przedsiębiorca”, warto sprecyzować, że w artykule przyjmowane będzie rozumienie przedsiębiorcy sensu largo, tzn. podmiotu łączącego funkcje właściciela i menedżera. Jednocześnie w publikacji przedstawione zostanie podejście do przedsiębiorczości, zgodnie z którym zostanie ona zdefiniowana jako grupa kompetencji warunkujących efektywne identyfikowanie i osiagganie celów organizacyjnych. Artykuł ma z założenia charakter przeglądowy, czyli zbiera $\mathrm{w}$ formie przeglądu wnioski z wcześniej opublikowanych prac w celu usystematyzowania pewnego obszaru wiedzy.

\section{Podmioty świadczące usługi prawne}

W artykule dotyczącym przedsiębiorczości prawników niezbędne jest wskazanie, jakie osoby można określić mianem „prawnika”. Przepisy prawa nie definiują jednoznacznie tego pojęcia, a ukończenie wyższych studiów prawniczych jest uznawane za zasadniczy, pierwszy, ale nie jedyny krok na drodze do uzyskania kwalifikacji zawodowych (Niewiadomski, 2008). Definicji prawnika lub zawodu prawniczego nie zawierają także przepisy prawa wspólnotowego Unii Europejskiej. Przepisy dyrektyw regulujących zasady wykonywania zawodów prawniczych posługują się wspólną kategorią prawnika na określenie enumeratywnie wymienionych zawodów wykonywanych w państwach członkowskich odpowiadających zawodowi adwokata lub radcy prawnego (Niewiadomski, 2008).

W aktualnym stanie prawnym brakuje kompleksowej regulacji dotyczącej świadczenia usług pomocy prawnej określającej, kto, kiedy, w jakim zakresie i na jakich warunkach może takie usługi świadczyć. Przepisy prawa regulują natomiast funkcjonowanie tzw. zawodów zaufania publicznego - zarówno prawniczych (adwokaci, radcowie prawni i notariusze), jak i pokrewnych (rzecznicy patentowi, doradcy podatkowi). W ustawach korporacyjnych nie ma wyraźnego przepisu wskazującego, że wykonywanie czynności z zakresu pomocy prawnej jest zastrzeżone wyłącznie dla radców prawnych i adwokatów. Czym innym jest bowiem wykonywanie zawodów radcy prawnego i adwokata, a czym innym wykonywanie czynności zawodowych prawnika. Usługi prawne mogą zatem świadczyć zarówno prawnicy wykonujący prawnicze lub pokrewne zawody zaufania publicznego, jak i prawnicy niewykonujący zawodu zaufania publicznego, a teoretycznie również przedsiębiorcy niebędący prawnikami (którzy powinni wówczas zatrudniać prawników). Prawnikami w takim rozumieniu są osoby, które ukończyły studia prawnicze w Polsce i uzyskały tytuł magistra prawa. W takich przypadkach zastosowanie maja przepisy ustawy o swobodzie działalności gospodarczej. Zgodnie z orzeczeniem Trybunału Konstytucyjnego (Wyrok TK z 26.11.2003 r.) prawnicy wykonujący zawody zaufania publicznego nie mają wyłączności na świadczenie pomocy prawnej, a obowiązkiem ustawodawcy jest ustrojowe uregulowanie kwestii świadczenia tej pomocy przez inne osoby niż adwokaci czy radcowie prawni. Szczególnie istotne jest określenie zakresu świadczenia takich usług i wyraźne ich oddzielenie od pomocy 
świadczonej przez ww. zawody zaufania publicznego. W zakres powinny wchodzić usługi prawnicze o mniej złożonym charakterze niż zakres usług wykonywanych przez adwokatów i radców prawnych. Zasadne jest odróżnienie usług stricte prawnych, które moga wykonywać tylko prawnicy posiadający specjalne uprawnienia zawodowe oraz kwalifikacje i wiedzę prawniczą zdobytą przede wszystkim w toku aplikacji i pracy zawodowej (adwokaci, radcowie prawni), od usług o mniej złożonym charakterze (np. pisanie projektów podań, udzielanie prostych porad prawnych), dla których wystarczające jest ukończenie studiów prawniczych. Dzięki takiemu podziałowi można wyróżnić kilka zawodów prawniczych, w ramach których świadczy się usługi prawne. Zaliczają się do nich zawody adwokata, radcy prawnego oraz doradcy prawnego. W zakres kwestii rozpatrywanych w niniejszym artykule wchodzi jedynie działalność adwokatów i radców prawnych. Można wyróżnić następujace przyczyny dokonania takiego wyboru: adwokaci i radcowie prawni posiadaja bowiem najszerszy zakres uprawnień, są profesjonalistami, funkcjonują na rynku od wielu lat i do niedawna tylko oni świadczyli usługi prawne. Ponadto te dwie grupy zawodowe, jako zrzeszone w korporacjach, cieszą się większym prestiżem. Doradcy prawni nie są zrzeszeni, jest ich mniej oraz spełniają funkcje pomocnicze.

\section{Istota przedsiębiorczości}

Przedsiębiorczość jest kategorią wieloznaczną, wieloaspektową i złożoną. Może być rozpatrywana w perspektywie ekonomii, nauk o zarządzaniu, prawnej, socjologicznej, psychologicznej, czy wreszcie w perspektywie łączącej wszystkie wymienione dyscypliny naukowe (Moczydłowska, 2010, s. 133). Dlatego pojęcie przedsiębiorczości może być rozumiane w różny sposób. Najczęściej przyjmuje się podział na dwa nurty: psychologiczny i ekonomiczny. Pierwszy $\mathrm{z}$ nich łączy przedsiębiorczość $\mathrm{z}$ osobą przedsiębiorcy i opisuje ją jako zbiór cech i umiejętności przedsiębiorczych. Tak rozumiana przedsiębiorczość jest ściśle związana z inicjatywą, aktywnością, innowacyjnością, wyrażaniem własnej indywidualności oraz świadomością własnej kreatywności. Jest ujmowana jako gotowość i zdolność do podejmowania i rozwiązywania nowych problemów, w sposób twórczy i nowatorski (Otoka i Wasilewska, 2007, s. 97).

Drugi nurt, charakterystyczny przede wszystkim dla nauk ekonomicznych (w tym zarzacdzania), to traktowanie przedsiębiorczości jako procesu prowadzącego do powstawania przedsiębiorstw i ich rozwoju (Moczydłowska, 2010, s. 137). Ujęcie procesowe obejmuje przejawienie inicjatywy (indywidualnie lub grupowo), połączenie zasobów do utworzenia przedsiębiorstwa, kontrolowanie funkcjonowania, swobodę działania, a także ponoszenie ryzyka (Piecuch, 2010, s. 42-44). W takim podejściu bycie przedsiębiorczym polega zatem na posiadaniu pomysłu, rozpoznaniu możliwości jego realizacji, przewidywaniu wyniku i oceny szans powodzenia. Dominuje zatem prakseologiczne podejście do przedsiębiorcy jako tego, który stawia cele oraz troszczy się o ich sprawną i skuteczną realizację (Ornarowicz, 2008, s. 132-133). Podsumowując tę część, można stwierdzić, że pierwszy nurt wskazuje cechy, jakimi powinna charakteryzować się osoba przedsiębiorcza, a drugi wskazuje działania, jakie musi ona podjąć, aby osiągnąć zamierzone cele (Piasecki, 1997, s. 33). W artykule przedstawione zostanie jednak inne, wielokontekstowe podejście do przedsiębiorczości. Zostanie ona zdefiniowana jako grupa kompetencji, warunkujacych efektywne identyfikowanie i osiąganie celów organizacyjnych. Takie ujmowanie przedsiębiorczości pozwala przyjąć, iż przedsiębiorczy może być konkretny człowiek, przedsiębiorczy może być zespó1, a nawet przedsiębiorcza może być cała organizacja, jeśli jest zarządzana przez przedsiębiorczych menedżerów stymulujących i wspierających przedsiębiorczość pracowników i współpracowników (Moczydłowska, 2010, s. 137). Wcześniej jednak opisane zostaną formalne aspekty przedsiębiorczości prawników oraz charakterystyka usług prawnych, jako profesjonalnych.

\section{Prawnik jako przedsiębiorca - ujęcie formalne}

Przedsiębiorczość i osoba przedsiębiorcy ściśle się ze sobą ściśle powiązane, należy zatem wyjaśnić, kim jest przedsiębiorca. W świetle przepisów prawa cywilnego przedsiębiorca jest osoba fizyczna, osoba prawna i jednostka organizacyjna, o której mowa w art. $33^{1} \S 1$ k.c., prowadząca we własnym 
imieniu działalność gospodarczą lub zawodową. Niemal identyczna definicja przedsiębiorcy została sformułowana w Ustawie o swobodzie działalności gospodarczej. Przedsiębiorca w tym rozumieniu jest zatem identyfikowany z właścicielem (KlonowskaMatynia i Palinkiewicz, 2013). W literaturze ekonomicznej podkreśla się jednak, że przedsiębiorcą jest także: menedżer lub nadzorca, innowator, osoba zatrudniająca czynniki produkcji, koordynator zasobów produkcyjnych, osoba wykazująca cechy przedsiębiorcze (Piecuch, 2010, s. 58). Właśnie takie szerokie ujęcie przedsiębiorcy zostanie przyjęte w tym opracowaniu. Wyraźnie odróżnia się ono od koncepcji „przedsiębiorcy autentycznego" (Johanisson i Lovstal 1996, s. 10). Zgodnie z przyjętym podejściem przedsiębiorcą może być założyciel firmy, jej właściciel oraz menedżer, a także osoba łącząca te funkcje (Bławat, 2003, s. 28-37). Taka perspektywa jest szczególnie zalecana w małych i średnich przedsiębiorstwach, a w takich właśnie formach najczęściej świadczone są usługi prawne. Warto również dodać, że przedsiębiorcy, w przeciwieństwie do osób w wielu innych zawodach albo zajęciach, nie mają wyraźnie określonych zakresów obowiązków, działalności i odpowiedzialności (Ardichvili, Cardozo i Ray, 2003). Najbardziej typowe dla przedsiębiorców są następujące działania: generowanie pomysłów na nowe produkty lub usługi, identyfikowanie okoliczności biznesowych odnoszących się do tych pomysłów, pozyskiwanie zasobów potrzebnych do opracowania tych pomysłów przez wprowadzanie na rynek nowego ryzykownego przedsięwzięcia (Turek, 2010, s. 183).

Historia uregulowania statusu radcy prawnego i adwokata jako przedsiębiorców jest związana $\mathrm{z}$ walką, jaką toczyły oba samorządy przeciwko próbom podporządkowania ich reżimowi prawnemu przewidzianemu dla wszystkich wykonujących działalność gospodarczą (Dryk 2013). I tak, w ustawie z dnia 6 kwietnia 1990 roku o zmianie ustawy o działalności gospodarczej pomoc prawna świadczona przez radców prawnych i adwokatów uznana została za działalność gospodarczą. W 1997 roku nastąpił odwrót od tej tendencji. Wskutek zniesienia art. 24 wspomnianej ustawy radcowie i adwokaci przestali być traktowani jako przedsiębiorcy, a do ich działalności odnosiły się jedynie przepisy szczegółowe
- regulujące wykonywanie ich profesji. Stan taki potwierdziła jeszcze ustawa z dnia 19 listopada 1999 roku - Prawo działalności gospodarczej, która wprost stwierdzała: „Świadczący pomoc prawną nie jest przedsiębiorcą w rozumieniu przepisów niniejszej ustawy". Dopiero wprowadzenie obecnie obowiązującej Ustawy o swobodzie działalności gospodarczej (art. 2) wyraźnie kwalifikuje przedstawicieli zawodów prawnych jako przedsiębiorców, a wykonywanie zawodów prawniczych jako działalność gospodarczą. Zakwalifikowanie radców prawnych i adwokatów jako przedsiębiorców nakłada na nich określone obowiązki (Dryk, 2013). Po pierwsze w zależności od formy prowadzenia swojej działalności podlegają oni obowiązkowi wpisu do właściwego rejestru: Centralnej Ewidencji Działalności Gospodarczej lub Krajowego Rejestru Sądowego. Po drugie muszą oni posiadać Numer Identyfikacji Podatkowej, którym posługują się w obrocie prawnym i gospodarczym Przedstawicieli obu zawodów można jednak uznać za przedsiębiorców szczególnego rodzaju (Dryk, 2013). Zgodnie z przepisami branżowymi powinni oni prowadzić działalność na zasadach uczciwej konkurencji oraz podlegają nie tylko kontroli przewidzianej przepisami ustawy o swobodzie działalności gospodarczej, ale również kontroli korporacyjnej, a także nadzorowi sprawowanego przez ministra sprawiedliwości.

Przedsiębiorcą może być zatem sam prawnik lub też szczególna forma organizacji usługowej, jaką jest kancelaria prawna (w przypadku działalności spółkach: jawnej, partnerskiej, komandytowej i komandytowo-akcyjnej przedsiębiorcą jest sama spółka). Warto jednak zauważyć, że ze względu na specyfikę usług prawnych do klasyfikacji kancelarii prawnych nie powinno się stosować powszechnie przyjętego w gospodarce podziału przedsiębiorstw, opartego na kryterium ilościowym, tj. liczbie zatrudnionych pracowników, wynikającego $\mathrm{z}$ art. 1 załącznika I do Rozporządzenia Komisji Europejskiej (WE) nr 800/2008 z dnia 6 sierpnia 2008 roku i potwierdzonego w Ustawie o swobodzie działalności gospodarczej. Zgodnie z tym podziałem w Polsce można wyróżnić następujące kategorie przedsiębiorstw: mikroprzedsiębiorstwa, przedsiębiorstwa małe, przedsiębiorstwa średnie oraz przedsiębiorstwa duże. Uwzględniając powy- 
Tabela 1. Rozróżnienie kancelarii prawnych ze względu na liczbę zatrudnionych prawników

\begin{tabular}{|c|l|l|l|l|}
\hline $\begin{array}{c}\text { Grupa } \\
\text { kancelarii }\end{array}$ & $\begin{array}{c}\text { Liczba } \\
\text { prawników }\end{array}$ & $\begin{array}{c}\text { Zasięg } \\
\text { terytorialny }\end{array}$ & \multicolumn{1}{|c|}{ Rodzaj klientów } & Organizacja i zarządzanie \\
\hline A & 1 & Cały kraj & $\begin{array}{l}\text { Mali przedsiębiorcy, osoby } \\
\text { nieprowadzące działalności } \\
\text { gospodarczej, klienci indy- } \\
\text { widualni }\end{array}$ & $\begin{array}{l}\text { Własne mieszkanie lub wyna- } \\
\text { jęty lokal, najczéściej brak } \\
\text { sekretariatu, czynności admi- } \\
\text { nistracyjne prawnik wykonu- } \\
\text { je samodzielnie }\end{array}$ \\
\hline B & $2-5$ & Cały kraj & $\begin{array}{l}\text { Mali przedsiębiorcy, osoby } \\
\text { nieprowadzące działalności } \\
\text { gospodarczej, klienci indy- } \\
\text { widualni }\end{array}$ & $\begin{array}{l}\text { Małe biuro - sekretariat, } \\
\text { niewielkie wsparcie admini- } \\
\text { stracyjne }\end{array}$ \\
\hline C & $6-30$ & $\begin{array}{l}\text { Duże } \\
\text { i średnie } \\
\text { miasta }\end{array}$ & $\begin{array}{l}\text { Średnie i duże przedsię- } \\
\text { biorstwa, klienci indywidu- } \\
\text { alni w przypadku dużych } \\
\text { i skomplikowanych spraw }\end{array}$ & $\begin{array}{l}\text { Średnie lub duże biuro, } \\
\text { rozbudowana administracja, } \\
\text { zarządza prawnik lub mene- } \\
\text { dżer }\end{array}$ \\
\hline D & $\begin{array}{l}30-100 \text { lub } \\
\text { więcej }\end{array}$ & $\begin{array}{l}\text { Warszawa } \\
\text { i inne naj- } \\
\text { większe } \\
\text { miasta }\end{array}$ & $\begin{array}{l}\text { Najwięksi klienci instytu- } \\
\text { cjonalni }\end{array}$ & $\begin{array}{l}\text { Duże biura, rozbudowana } \\
\text { administracja i struktura } \\
\text { organizacyjna, zarządza } \\
\text { grupa prawników }\end{array}$ \\
\hline
\end{tabular}

Źródło: opracowanie własne na podstawie raportu Prawnik dla każdego. Czy należy urzędowo ograniczać ceny usług prawniczych (2007).

żej opisany podział, należy stwierdzić, iż dominująca część kancelarii prawnych w Polsce należy do grupy mikro lub małych przedsiębiorstw, a tylko kilka największych zalicza się do grupy przedsiębiorstw średnich. Wobec tego należy opracować inny sposób systematyzacji kancelarii prawnych. $\mathrm{Na}$ potrzeby artykułu przyjęto następujące kryteria rozróżnienia kancelarii prawnych: liczba zatrudnianych prawników; zasięg terytorialny; rodzaj obsługiwanych klientów; sposób zarządzania kancelarią. Uwzględniając kryterium ilościowe, można wyróżnić cztery grupy kancelarii:

a) jednoosobowe kancelarie adwokackie i radcowskie, obsługujące głównie klientów indywidualnych i małe przedsiębiorstwa; jest ich najwięcej w całym kraju,

b) małe (zatrudniające 2-5 prawników) kancelarie adwokackie i radcowskie, obsługujące głównie klientów indywidualnych oraz małe i średniej wielkości przedsiębiorstwa,

c) średniej wielkości (zatrudniające 6-30 prawników) kancelarie nastawione na obsługę klientów instytucjonalnych,

d) duże (zatrudniające więcej niż 30 prawników) międzynarodowe kancelarie i największe polskie kancelarie obsługujące zagranicznych inwestorów i naj- większe polskie podmioty; występują tylko w Warszawie i w innych największych miastach.

W tabeli 1 przedstawione zostały wszystkie cztery podstawowe typy kancelarii z uwzględnieniem wyżej wymienionych kryteriów, czyli: liczby zatrudnionych prawników, zasięgu terytorialnego, rodzaju obsługiwanych klientów oraz stosowanych sposobów zarządzania.

W dalszej części opisane zostaną usługi prawne jako usługi profesjonalne oraz kluczowe kompetencje prawników, które decydują o ich przedsiębiorczości.

\section{Usługi prawne jako usługi profesjonalne}

Usługi prawne są świadczeniem o charakterze intelektualnym, dlatego o ich należytym wykonywaniu decydują przede wszystkim inwencja, wiedza, wykształcenie oraz najwyższe kwalifikacje osób je wykonujących. Przedsiębiorczość w tych usługach mogłaby być zatem utożsamiana $z$ teorią usług profesjonalnych. Usługa profesjonalna jest świadczeniem profesjonalisty, które dzięki jego talentom umożliwia, w procesie interakcji z klientem, stworzenie unikalnej wiązki korzyści, dającej gwarancję 
realizacji dzieła zgodnie $\mathrm{z}$ oczekiwaniami klienta (Chłodnicki, 2004). Usługi profesjonalne opierają się głównie na osobowości profesjonalisty i jego indywidualności. $\mathrm{Na}$ istotę profesjonalizmu składa się mistrzowskie opanowanie sztuk oraz odpowiednia postawa moralna warunkujacca dochodzenie do mistrzostwa (Rogoziński, 2001, s. 16).

Podstawą profesjonalizmu jest posiadanie ugruntowanej i specjalistycznej wiedzy - takiej, której usługobiorca nie posiada. Wiedza specjalistyczna jest tylko jednym z budulców autorytetu profesjonalisty, natomiast to autorytet profesjonalisty przesądza o charakterze jego relacji z klientami. Relacja ta opiera się na zaufaniu, jakim klient obdarza profesjonalistę, oczekując $\mathrm{w}$ zamian $\mathrm{z}$ jego strony zaangażowania. O profesjonalizmie świadczeniodawcy decyduje zatem nie tylko jego wiedza i umiejętność jej przetwarzania, lecz także wiele innych czynników, takich jak: osobowość, umiejętności przekazywania informacji, dbałość o klienta czy kultura osobista.

Profesjonalista powinien spełniać cztery następujące warunki (Rogoziński, 2009, s. 32-33):

- posiadać odpowiednio wysokie kwalifikacje,

- dojrzała osobowość specjalisty powinna być uformowana stosownie do wymagań i oczekiwań dotyczących osób zaufania publicznego,

- powinien przynależeć do korporacji w formalny sposób,

- powinien mieć świadomość współodpowiedzialności za dobrostan wspólnoty powierzonej jego pieczy.

Na przedsiębiorczość prawników wpływ ma też fakt, że zawody prawnicze adwokata oraz radcy prawnego, będące przedmiotem zainteresowania niniejszego artykułu, zaliczane są do tzw. wolnych zawodów. Wolny zawód oznacza osobiste i systematyczne wykonywanie wewnętrznie spójnego zespołu czynności o charakterze intelektualnym, wymagających wysokich kwalifikacji, w zamian za honorarium bezinteresownie ustalone, służące zapewnieniu świadczeń i usług klientom oraz ochronie istotnych wartości interesu ogólnego, zgodnie z obowiązującymi normami prawnymi i zasadami etycznymi (Jacyszyn, 2004, s. 21). Według innej definicji (Antkowiak, 2010, s. 170) osoby wykonujące wolny zawód powinny mieć wysokie kwalifikacje oraz przygotowanie, ponieważ działania podejmowane przez przedstawicieli tych profesji są niezwykle złożone. Ponadto wolne zawody muszą być wykonywane samodzielnie oraz w sposób nieskrępowany. Samodzielność działania powoduje powstanie szczególnej więzi pomiędzy osobą wykonującą wolny zawód a odbiorcą jej świadczeń i usług, która to więź jest oparta na zaufaniu. Władza publiczna nie powinna ingerować w metody działań stosowane w obrębie wolnych zawodów. Każdy wolny zawód powinien mieć swój samorząd, zapewniający samodzielność i niezależność wobec administracji rządowej.

\section{Kompetencje przedsiębiorczych prawników}

Poszukując odpowiedzi na pytanie, jakie cechy powinien posiadać przedsiębiorca, coraz częściej można się spotkać z odwołaniami do teorii kompetencji (Bławat 2003, s. 91). W niniejszym opracowaniu przedstawione zostana przede wszystkim kompetencje prawników, czyli ich możliwości wynikajace $\mathrm{z}$ osobowości, doświadczenia i kwalifikacji oraz innych atrybutów osobowych. Oznacza to zatem przyjęcie podejścia behawioralnego, nawiązującego do charakterystyki, a popularnego wśród takich badaczy jak np.: D.C. McClleland, T. Lau, D.G. Mitton czy E. Chell. W pewnym zakresie opisane zostaną też warunki zewnętrzne (np.: ekonomiczne, polityczne, kulturowe, społeczne), które sprzyjają ujawnianiu zachowań przedsiębiorczych wśród prawników. Artykuł został oparty na paradygmacie marketingowego zarządzania organizacją świadczącą usługi profesjonalne. Zgodnie z jego założeniami przedsiębiorczy prawnik powinien legitymować się nie tylko specjalistycznymi, ale również specjalnymi ,jakościowymi” kompetencjami, uwzględniającymi oczekiwania klientów. Dlatego występuje on w poczwórnej roli: przedsiębiorcy, usługodawcy-wykonawcy, menedżera zarządzającego personelem zestrojonym z cyklem obsługi usługobiorcy oraz marketera (Rogoziński, 2012).

Podstawowym komponentem usługi profesjonalnej są zasoby organizacji usługowej (Gummesson, 1979, s. 86). Termin „zasoby” w literaturze anglojęzycznej często zastępowany jest określeniem „kompetencje” (competency). Są one kategorią obejmującą wszystkie czynniki wpływające na zdolność do realizacji określonego świadczenia. 
Mogą one być rozpatrywane na poziomie zarówno indywidualnym - dotyczą osoby profesjonalisty, jak i na poziomie organizacyjnym - opisują kompetencje kancelarii. Kompetencje, rozumiane jako wiedza, umiejętności i cechy niezbędne do efektywnego wykonywania zadań (Słownik Języka Polskiego, http) umożliwiają sprawne zarządzanie.

B. Nogalski za kompetencje uznaje konglomerat zdolności, wiedzy, wykształcenia, doświadczenia, innych predyspozycji i cech osobowości (Nogalski i Śniadecki, 2001). Zdaniem G. Filipowicza pojęcie „kompetencje" zawsze występuje w liczbie mnogiej. Niezwykle trudno jest wyizolować pojedynczą kompetencję i traktować ją jako właściwość całkowicie oderwaną od innych kompetencji, niezależna (Filipowicz, 2004, s. 36-37). W literaturze naukowej można znaleźć wiele definicji terminu „kompetencje”. Przykładowo kompetencje są definiowane jako:

- „zespół cech danej osoby, na który składają się charakterystyczne dla tej osoby elementy, takie jak motywacja, cechy osobowości, umiejętności, samoocena związana $\mathrm{z}$ funkcjonowaniem $\mathrm{w}$ grupie oraz wiedza, która ta osoba sobie przyswoiła i którą się posługuje" (Whidett i Hollyforde, 2003, s. 13);

- ,pojęcie szersze od kwalifikacji, obejmujące ogół trwałych właściwości człowieka, tworzących związek przyczynowo-skutkowy z osiaganymi przez niego wysokimi lub ponadprzeciętnymi efektami pracy, które mają wymiar uniwersalny".

Bardzo ciekawe jest również podejście prezentowane przez M. Kossowską i I. Sołtysińską (Kossowska i Sołtysińska 2002, s. 14) zakładające, że podstawą kompetencji jest wiedza, która jest rozważana na trzech poziomach:

- wiedzy w potocznym rozumieniu (wiedza deklaratywna - wiem, co),

- umiejętności (wiedza proceduralna wiem, jak i potrafię),

- postawy (chcę i jestem gotów wykorzystać swoją wiedzę).

W literaturze przedmiotu często można spotkać podział kompetencji na podstawowe i wyróżniające. Zdaniem C.R. Stonera (Chłodnicki, 2004, s. 22) kompetencje podstawowe stanowią umiejętności i czynniki (materialne i niematerialne) pozwalające na realizację przez profesjonalistę rdzenia produktu usługowego i stanowiące o nazwie jego profesji. Kompetencje wyróżniające określane są natomiast przez umiejętności, czynności czy możliwości, które pozwalają firmie na działania na poziomie określanym jako szczególnie wysoki w porównaniu do konkurencji. Mogą być one rozpatrywane $\mathrm{z}$ pułapu indywidualnego (kompetencje osoby) lub organizacyjnego (kompetencje organizacji). Inaczej opisywane zagadnienie ujął A. Pocztowski, który również wyróżnia: kompetencje podstawowe (treshold competiences), mające zasadnicze znaczenie dla prawidłowego wykonywania danej pracy oraz kompetencje wyróżniające (differentiating competiences) - kompetencje odróżniające pracownika efektywnego od pozostałych (Pocztowski, 2003, s. 155).

Przykładowy zestaw kompetencji kierowniczych, w zakresie kompetencji podstawowych to: wiedza fachowa, rozwiązywanie problemów, komunikowanie się, kształtowanie relacji oraz korzystanie z usług doradców. Do kompetencji wyróżniających A. Pocztowski zaliczył umiejętności przywódcze, empatię, gotowość uczenia się, tolerancję dla niejednoznaczności, nastawienie na kreatywność, orientację na przyszłość, świadomość wartości.

Omawiając kompetencje przedsiębiorcze związane $\mathrm{z}$ bezpośrednio z osobą przedsiębiorcy, warto odwołać sie do modelu sformułowanego przez B. Glinkę i S. Gudkova. Model ten powstał w wyniku analizy badań zagranicznych autorów (przede wszystkim E. Boyatzisa) i składa się z pięciu kluczowych kompetencji przedsiębiorczych, tj. cech osobowości, poczucia własnej skuteczności, motywów działań przedsiębiorczych, wiedzy ogólnej i specjalistycznej oraz mechanizmów poznawczych prowadzących do założenia, przetrwania oraz rozwoju przedsiębiorstwa (Glinka i Gudova, 2011, s. 122). Z kolei B. Edvardson wyróżnił 5 następujących form kompetencji menedżera profesjonalnej praktyki (Edvardson, 1994, s. 171):

1) kompetencje podstawowe - znajomość koncepcji i celów działania kancelarii,

2) kompetencje profesjonalne - posiadanie odpowiedniego wykształcenia i doświadczenia oraz „bycie profesjonalistą”,

3) kompetencje społeczne - wpływaja zarówno na sposób obsługi klienta, jak i na umiejętność współpracy w grupie,

4) kompetencje kryzysowe - umiejętność postępowania w sprawach trudnych, np.: 
postępowanie $\mathrm{z}$ niezadowolonym klientem,

5) kompetencje biznesowe - rozumienie ekonomicznych skutków swoich działań. Przy omawianiu zagadnienia przedsiębiorczości prawników pomocny może się okazać podział zaproponowany przez J. Sandberga (Sandberg, 1989), zgodnie z którym można wyróżnić 5 elementów kompetencji menedżerów organizacji usługowych:

1) wiedza teoretyczna (theoretical knowledge) - wiedza specjalistyczna, ekspercka, nabyta w wyniku studiów, z książek, szkoleń itp.,

2) wiedza praktyczna (practical knowledge) - umiejętności i biegłość w działaniach; na ogół wynika z doświadczenia. Tę wiedzę trudno jest przekazać. Można opisać lub pokazać, jak zachować się w danej sytuacji, ale dopiero samodzielne rozwiązywanie problemów daje wiedzę praktyczną,

3) sztuka budowania sieci i funkcjonowania w nich (network) - polega na umiejętności dostępu do sieci, czyli powiązań, kontaktów osobistych menedżera oraz dostępu do baz danych lub innych źródeł informacji - tzw. kapitał relacji,

4) zdolności (capacity) - pewność siebie, poczucie własnej wartości, które udziela się pracownikom, odwaga do podejmowania działania, ale także znajomość własnych ograniczeń i samokrytycyzm,

5) umiejętność postrzegania (conception) - sposób, w jaki widzimy otaczający nas świat wpływa na to, jak się zachowujemy. Sposób postrzegania obowiązków przez pracowników wpływa na to, jak wykonują powierzone im zadania. Zależy to od osobowości, ale też od sposobu zdefiniowania i wyjaśnienia zleconych pracownikom zadań.

W pewnym stopniu, przy opisie cech przedsiębiorczego prawnika można zastosować również zestaw 10 cech i umiejętności idealnego prawnika - partnera (menedżera) według Ryszarda Sowińskiego (Sowiński, 2011). Zgodnie z tym podziałem jest on: dojrzałym człowiekiem, przywódcą, efektywnym prawnikiem, osobą godną zaufania, postępuje zgodnie z cenionymi w firmie wartościami, potrafi pracować w zespole, przyciąga nowych klientów i nowe zlecenia, jest mistrzem dla młodszych prawników, przyjmuje odpowiedzialność za siebie i swoje otoczenie oraz jest przedsiębiorczy.
Podsumowując powyższe rozważania, można zaproponować autorską koncepcję kompetencji przedsiębiorczego prawnikamenedżera kancelarii prawnej, składającą się z czterech płaszczyzn interpretacji:

1) kompetencje merytoryczne oparte na wiedzy profesjonalisty $(\mathrm{Kw})$ - szeroka wiedza prawnicza sprawiająca, że jest on autorytetem dla innych,

2) kompetencje marketingowe (Km) umiejętność rozmowy z klientem, autoprezentacji, promocji itd.,

3) kompetencje z zakresu zarządzania $(\mathrm{Kz})$ - najszerszy zestaw kompetencji wynikających $\mathrm{z}$ teorii marketingu relacyjnego np.: cechy osobowościowe, przywództwo i kierowanie prawnikami, motywowanie, kapitał relacji, zarządzanie relacjami z klientem,

4) kompetencje w kontekście aksjologicznym $(\mathrm{Ka})$ - rozpatrywanie kompetencji w sensie aksjologicznym oznacza uznanie działania prawnika nie tylko za użyteczne, sprawne i zyskowne dla kancelarii, ale przede wszystkim za przynoszące dobro pracownikom i klientowi. Etyczna koncepcja dobra wiąże się również z dobrostanem środowiska, stąd też dobrze wykonana usługa prawna oddziałuje na zachowanie ładu zarówno prawnego, jak i społecznego.

W tabeli 2 wymieniono szczególne cechy, które powinni posiadać prawnicy, aby z powodzeniem zdobywać i utrzymywać klientów na konkurencyjnym rynku usług prawnych.

Posiadanie wyżej wymienionych cech osobowych ma pozytywny wpływ na przedsiębiorczość radców prawnych i adwokatów. Działalność przedsiębiorcza prawników powinna być jednak stymulowana. Pobudzanie do działań przedsiębiorczych jest procesem wielowymiarowym, dynamicznym, a ponadto zorganizowanym, ustrukturyzowanym i funkcjonalnym. Po pierwsze, obejmuje stymulowanie działań przedsiębiorczych na poziomie jednostkowym. W takim przypadku działania przedsiębiorcze podejmowane przez jednostki powinny być postrzegane przez nie jako szansa i pozytywnie odbierane przez społeczeństwo (Kolasińska, 2010, s. 164). Po drugie, procesowe działanie przedsiębiorcze może mieć wymiar polityczny, instytucjonalny lub społeczny (Kolasińska, 2010, s. 164). W przypadku prawników jest to zadanie szczególnie utrudnione, z uwagi 


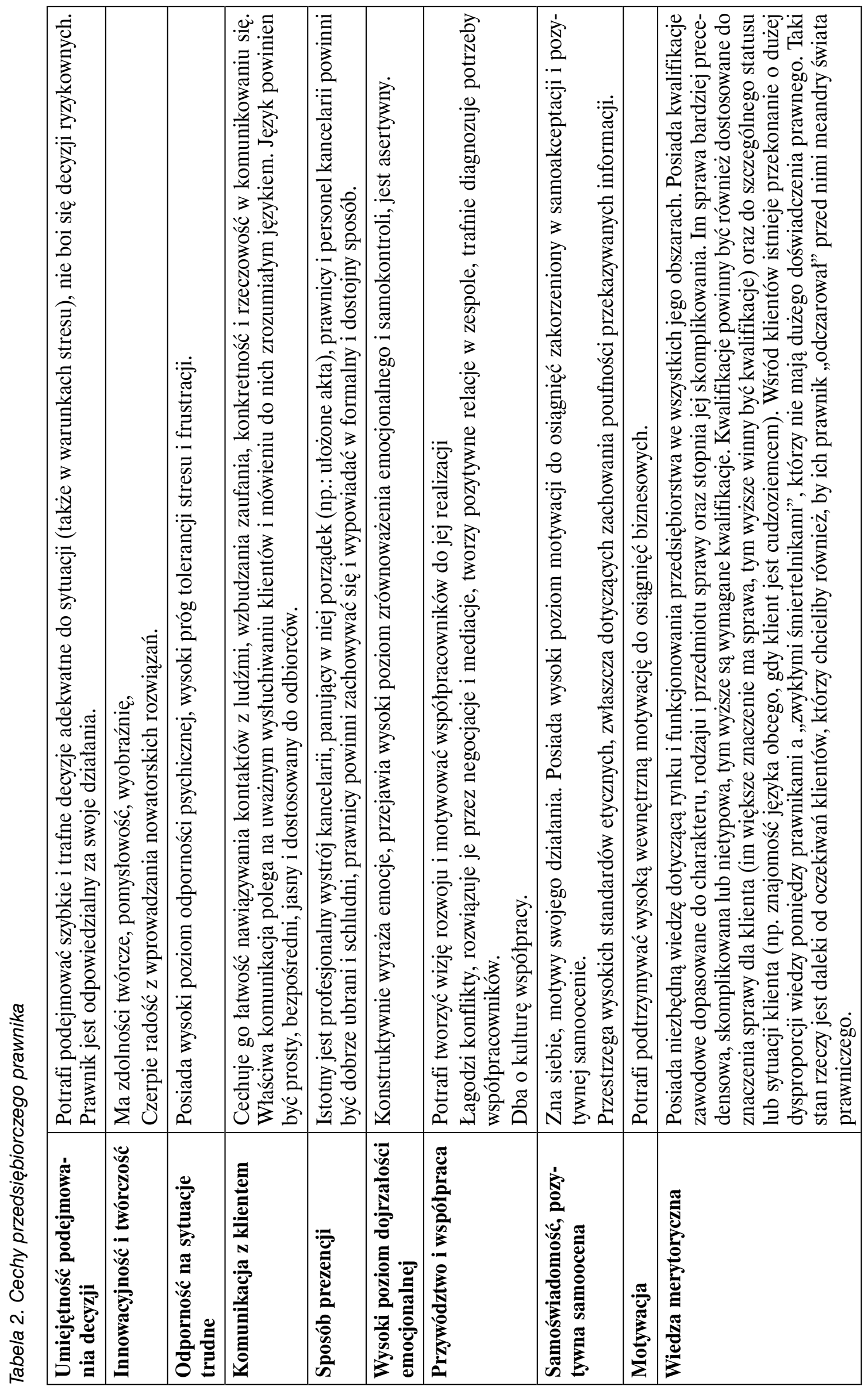




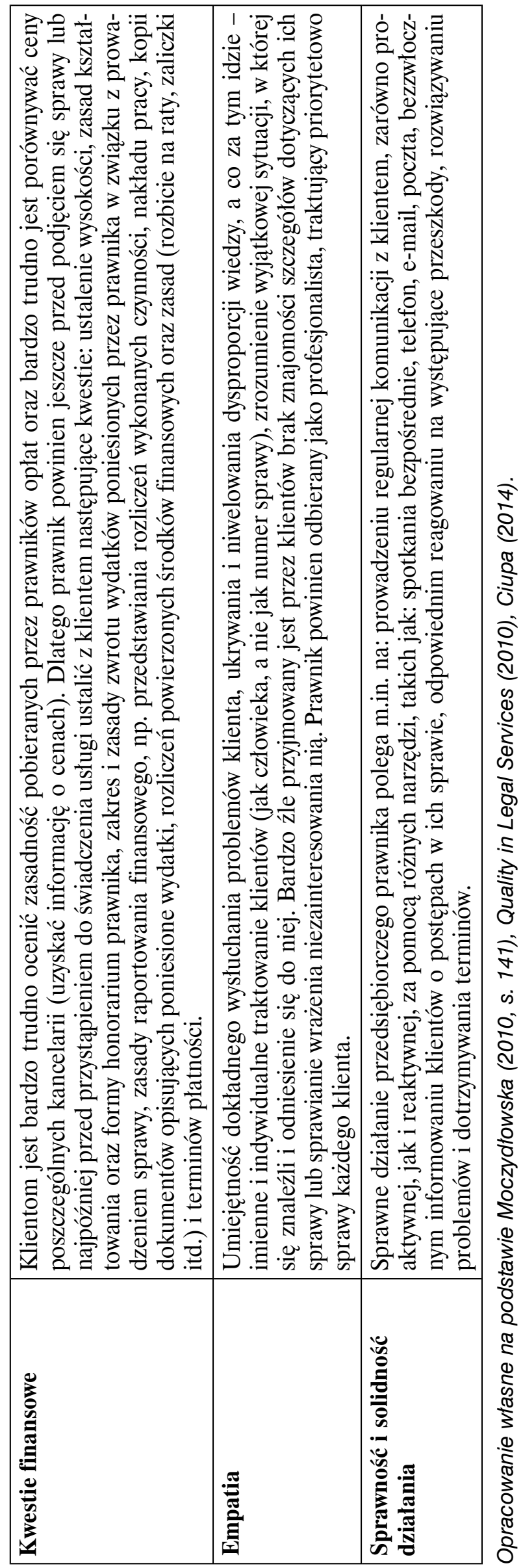


na charakter zawodu, rozbudowane zakazy wynikające $\mathrm{z}$ korporacyjnych zasad etyki zawodowej oraz zachowawcze podejście organów samorządu zawodowego.

\section{Zakończenie}

Uznanie prawników za przedsiębiorców pozwala spojrzeć na rynek usług prawnych z nowej perspektywy. Co prawda, usługi prawne, jako usługi profesjonalne, są świadczeniem o charakterze intelektualnym, dlatego o ich należytym wykonywaniu decydują przede wszystkim inwencja, wiedza, wykształcenie oraz najwyższe kwalifikacje osób je wykonujących. Jednocześnie jednak, wobec intensywnej konkurencji na rynku, od prawników wymaga się również coraz czéściej działań przedsiębiorczych, w których oprócz wiedzy i umiejętności jej przetwarzania istotne są również takie czynniki jak: osobowość, umiejętności przekazywania informacji dbałość o klienta. W artykule wskazano cechy przedsiębiorczych prawników - ich posiadanie powinno zapewnić sukces rynkowy. Szczególnie ważne jest, by prawnicy byli otwarci na zmiany, odpowiedzialni i gotowi do ponoszenia ryzyka, a także by posiadali zdolność budowania sieci relacji społecznych.

\section{Bibliografia}

Antkowiak, P. (2010). Czy to koniec zawodów prawniczych w Europie? - przypadek Polski, Refleksje. Pismo naukowe studentów i doktorantów WNPiD $U A M, 1$.

Ardichvili, A., Cardozo, R. i Ray, S. (2003). A theory of entrepreneurial opportunity identification and development. Journal of Business Venturing, 18.

Bławat, F. (2003), Przedsiębiorca $w$ teorii przedsiębiorczości i praktyce małych firm. Gdańsk: Gdańskie Towarzystwo Naukowe.

Chłodnicki, M. (2004). Ustugi profesjonalne przez jakość do lojalności klientów. Poznań: Wydawnictwo AE w Poznaniu.

Ciupa, S., Jak określać wymagania i oczekiwania wobec prawnika. Pozyskano z: http://www.kancelariacsw.pl/index.php?option $=$ com_content\&vie$\mathrm{w}=$ article $\& \mathrm{id}=88 \&$ Itemid 53 (22.04.2014).

Dryk, P. (2013), Radca prawny $i$ adwokat jako przedsiębiorca. Pozyskano z: http://studentprawa.pl/ prawo-w-praktyce/item/941-radca-prawny-i-adwokat-jako-przedsiebiorca (25.08.2015).

Edvardson, B., Thomasson, B. i Ovretveit, J. (1994). Quality of Service. Making it really work. McGraw-Hill.
Filipowicz, G. (2004). Zarzadzanie kompetencjami zawodowymi. Warszawa: PWE.

Glinka, B. i Gudkova, S. (2011). Przedsiębiorczość. Warszawa: Wolters Kluwer Polska

Gummesson, E. (1979). Models of Professional Services Marketing, za: K. Rogoziński (2000). Ustugi rynkowe. Poznań: Wydawnictwo AE w Poznaniu.

Jacyszyn, J. (2004). Wykonywanie wolnych zawodów $w$ Polsce. Warszawa: LexisNexis.

Johannisson, B. i Lovstal, E. (1996). Contrasting Business Rationales in SME's:Appropriate Bridging Strategies, Piacenza, Rent X Conference Proceedings. Cyt za: Bławat, F. (2003). Przedsiębiorca $w$ teorii przedsiębiorczości i praktyce matych firm. Gdańsk: Gdańskie Towarzystwo Naukowe.

Kolasińska, E. (2010). Stymulowanie działań przedsiębiorczych, w: P. Kulawczuk i A. Poszewiecki (red.), Behawioralne determinanty rozwoju przedsiębiorczości $w$ Polsce. Behawioralny wymiar przedsiębiorczości. Gdańsk: Fundacja Rozwoju Uniwersytetu Gdańskiego.

Klonowska-Matynia, M. i Palinkiewicz, J. (2013). Przedsiębiorczość w teorii ekonomicznej, Zeszyty Naukowe Politechniki Koszalińskiej, 17.

Kossowska, M. i Sołtysińska, I. (2002). Szkolenia pracowników a rozwój organizacji. Kraków: Oficyna Ekonomiczna.

Moczydłowska, J. (2010). Przedsiębiorczość - perspektywa behawioralna. W: P. Kulawczuk i Poszewiecki A. (red.), Behawioralne determinanty rozwoju przedsiębiorczości $w$ Polsce. Behawioralny wymiar przedsiębiorczości. Gdańsk: Fundacja rozwoju Uniwersytetu Gdańskiego

Niewiadomski, T. (2008). Świadczenie usług prawniczych jako działalność gospodarcza, Edukacja Prawnicza, 5.

Nogalski, B. i Śniadecki, J. (2001), Umiejętności menadżerskie $w$ zarządzaniu przedsiębiorstwem. Bydgoszcz: OPO.

Ornarowicz, U. (2008). Menedżer XXI wieku. Warszawa: Oficyna Wydawnicza SGH.

Piasecki, B. (1997). Przedsiębiorczość i mata firma. Łódź: Wydawnictwo Uniwersytetu Łódzkiego.

Piecuch, T. (2010). Przedsiębiorczość. Podstawy teoretyczne. Warszawa: C.H. Beck.

Pocztowski, A. (2003). Zarzadzanie zasobami ludzkimi. Strategie - procesy - metody. Warszawa: PWE.

Prawnik dla każdego. Czy należy urzędowo ograniczać ceny ustug prawniczych (2007). Warszawa: Instytut Sobieskiego.

Quality in Legal Services (2010). Vanilla Research for the Legal Services Consumer Panel.

Rogoziński, K. (2001). O profesjonalizmie kształtującym osobowość oraz jego wpływie na kulturę organizacji usługowej. W: K. Rogoziński (red.), 
Materiaty z konferencji pt. „Marketing ustug profesjonalnych. Kultura organizacji - osobowość profesjonalisty”. Poznań.

Rogoziński, K. (2009). Zarządzanie profesjonalna praktyka medyczna. Warszawa: Wolters Kluwer Polska.

Rogoziński, K. (2012). Kompetencje menedżera organizacji usługowej. W: K. Rogoziński i A. Panasiuk, Zarzadzanie organizacjami ustugowymi. Poznań: Wydawnictwo Uniwersytetu Ekonomicznego w Poznaniu.

Sandberg, J. (1989). Competence analysis as a strategic tool, working paper Barcelona. Cyt. za: Edvardson, B., Thomasson, B. i Ovretveit, J. (2004), Quality of Service. Making it really work. McGraw-Hill.

Stownik Języka Polskiego, http://sjp.pwn.pl/szukaj/ kompetencje (22 czerwca 2015 roku).

Sowiński, R., 10 cech idealnego Partnera Kancelarii. Pozyskano z: http://www.nowoczesnakancelaria.pl (28.06.2011).
Turek, M. (2010). Przedsiębiorca jako podmiot działalności gospodarczej w aspekcie behawioralnym i kognitywnym. W: P. Kulawczuk i A. Poszewiecki (red.), Behawioralne determinanty rozwoju przedsiębiorczości $w$ Polsce. Behawioralny wymiar przedsiębiorczości. Gdańsk: Fundacja Rozwoju Uniwersytetu Gdańskiego.

Ustawa z dnia 2 lipca 2004 r. o swobodzie działalności gospodarczej, Dz.U. 2004 nr 173 poz. 1807.

Wasilewska, J. i Otoka, M. (2007), Przedsiębiorczość a ubóstwo. W: D. Perło (red.), Ekonomiczne $i$ spoteczne aspekty ubóstwa $w$ województwie podlaskim. Białystok: Wydawnictwo Uniwersytetu w Białymstoku.

Whiddett, S. i Hollyforde, S. (2003) Modele kompetencyjne w zarzqdzaniu zasobami ludzkimi. Kraków: Oficyna Ekonomiczna.

Wyrok Trybunału Konstytucyjnego z 26.11.2003 r., SK 22/02, OTK-A Nr 9/2003, poz. 97. 